\title{
Comparison of Acinetobacter baumannii multidrugs resistant Isolates obtained from French and Tunisian hospitals
}

\author{
Ben Othman $A^{\star 1}$, Burucoa $\mathbf{C}^{2}$, Battikh $\mathrm{H}^{1}$, Zribi $\mathbf{M}^{1}$, Masmoudi $\mathrm{A}^{1}$ and Fendri $\mathrm{C}^{1}$
}

${ }^{1}$ Microbiology laboratory- UR04SP08, Rabta University Hospital, Tunis, Tunisia

${ }^{2}$ Microbiology laboratory- Poitiers university hospital , EA 4331 “Laboratoire Inflammation Tissus Epithéliaux Cytokines”, Poitiers, France

\begin{abstract}
Objectives: The aim of this study was to assess whether there are differences between the clustering of isolates collected between 2003 and 2005 from two different hospitals in Tunisia and France.

Methods: A selection of 62 isolates of $A$. baumannii was studied; 31 from the French Hospital (Poitiers) and 31 from Tunisian Hospital (Rabta). Antibiograms were done using the disc diffusion method. The presence of integrons class 1 and 2 was studied by PCR. Molecular relationship was studied by Random Amplified Polymorphic DNA (RAPD) and Pulsed Field Gel Electrophoresis (PFGE). The sequence typing of adeB gene was determined to identify intraspecific groups.

Results: The present study successfully focuses to compare epidemiologic status between two hospitals study. PFGE and RAPD methods were useful to distinguish epidemic and endemic clones in the two collections study. Sequence analysis of an 850-bp internal fragment drug efflux gene ade $B$ revealed 9 novel sequence types (STs).

Conclusion: We, statistically, found no significant difference related to the epidemiological situation. This study showed that different genetic types of A.baumannii were found in the two collection strains. Epidemics ones were essentially confined in the ICU and were persisting during the two years study. However, more control procedures had to be used on these clones for the Tunisian hospital.
\end{abstract}

Keywords: Acinetobacter baumannii; Epidemiology; nosocomial infections; antibiotic resistance; $a d e B$ gene

\section{Introduction}

A.baumannii is a Gram negative coccobacillus, largely confined in the nosocomial environment that emerged as an important nosocomial pathogen in recent years. Hospital outbreaks caused by this organism have increased worldwide $[1,2,3,4]$. It was also demonstrated that $A$. baumannii multiresistant strains were essentially isolated in intensive care units (ICU) in critically ill persons $[5,6,7]$. The aim of this study was to compare the clustering relationship of $A$. baumannii isolates between two different hospitals, located in Tunisia and France. This study was not intended to be a formal assessment of the epidemiological aspects of this pathogen.

\section{Material and methods}

\section{Bacterial strains}

Our study was performed on a selected collection of 62 isolates of A. baumannii: 31 from the French University Hospital (Poitiers) and 31 from the North African University Hospital (Tunisia). These isolates were selected among multidrug-resistant $A$. baumannii isolates recovered during the increased occurrence during (2003-2005) in both hospitals essentially in the intensive care units (ICU). The isolates were selected in relation to their presumptive cases of cross-infection, based on their antibiotic susceptibility profile and their origin in time and space. Identification of $A$. baumannii strains was based on standard biochemical tests and morphologic characteristics by systematic API $32 \mathrm{GN}$ (Biomerieux). The growth at $44^{\circ} \mathrm{C}$ showed that all the strains studied are baumannii.

\section{Epidemiological data collection}

In order to provide a good comparison between the two contrasting hospital situations, a few epidemiological data were collected. The French teaching hospital had 1579 beds with two units of intensive care (surgery and medical care) that support 58 beds and accept 60 000 patients each year. It has also two intensive paediatric units with 16 beds.

Tunisian hospital has a smaller capacity of acceptance: 960 beds with two units of intensive care (surgical and medical care) that supports 34 beds and accept 23000 patients each year. The paediatric intensive care unit supports 40 beds. The two hospitals were available as well for all patients sent by other university hospitals or regional ones that don't have this unit. But, the number of strains isolated each year was higher in the Tunisian hospital with 100 to 110 strains against 40 to 70 in the European one.

In order to explain this difference of resistance level, the consumption of Imipenem was determined and expressed in defined daily dose (DDD) of imipenem per 1000 hospital days (DDD/ 1000 hospital days). According to the recommendations of the WHO (World Health Organisation), DDD must be always $\leq 2 \mathrm{~g}$ for imipenem.

\section{Antibiotyping}

Antibiograms were determined by the disk diffusion method for 8 selected antibiotics shown to be useful to distinguish Acinetobacter

*Corresponding authors: Ben othman Asma, Hospital Microbiological laboratory, CHU La Rabta, Tunis, Tunisie, Tel: +216 715706 93; Fax: +21671570693 (Tunisia); E-mail: asmabenothman@gmail.com

Received December 25, 2010; Accepted February 23, 2011; Published February 25, 2011

Citation: Ben Othman A, Burucoa C, Battikh H, Zribi M, Masmoudi A, et al. (2011) Comparison of Acinetobacter baumannii multidrugs resistant Isolates obtained from French and Tunisian hospitals. J Bacteriol Parasitol 2:106. doi:10.4172/2155 9597.1000106

Copyright: ( 2011 Ben Othman A, et al. This is an open-access article distributed under the terms of the Creative Commons Attribution License, which permits unrestricted use, distribution, and reproduction in any medium, provided the original author and source are credited. 
Citation: Ben Othman A, Burucoa C, Battikh H, Zribi M, Masmoudi A, et al. (2011) Comparison of Acinetobacter baumannii multidrugs resistant Isolates obtained from French and Tunisian hospitals. J Bacteriol Parasitol 2:106. doi:10.4172/2155-9597.1000106

Page 2 of 7

clusters [8,9]: gentamicin (GM 10UI/ml), imipenem (IPM $10 \mu \mathrm{g} / \mathrm{ml})$, tobramycin (TOB $10 \mu \mathrm{g} / \mathrm{ml})$, amikacin (AN $30 \mu \mathrm{g} / \mathrm{ml})$, tetracycline (TET $30 \mu \mathrm{g} / \mathrm{ml})$, ciprofloxacin $(\mathrm{CIP} 5 \mu \mathrm{g} / \mathrm{ml})$, ceftazidime $(\mathrm{CAZ} 30 \mu \mathrm{g} / \mathrm{ml})$ and rifampicin (RIF $30 \mu \mathrm{g} / \mathrm{ml}$ ). This technique was done in duplicate in the two hospitals study. A Mueller Hinton agar medium (Biorad), was inoculated with a bacterial suspension $0.5 \mathrm{Mc}$ Farland opacity and was incubated $24 \mathrm{~h}$ at $37^{\circ} \mathrm{C}$. Inhibition areas were measured as the diameter of the inibition zone in $\mathrm{mm}$. Antibiogram similarity coefficients were calculated and analysed by euclidian distance used as a measure of dissimilarity by the "Taxotron Antibiotyping software" (Grimont, Institut Pasteur, Paris, France).

\section{PCR detection of Integrons 1 and 2}

Presence of integron class 1 was detected by PCR using the 5' and 3' conserved segments. Primers used were 5'CS (GGCATCCAAGCAGCAAG) and 3'CS (AAGCAGACTTGACCTGA) [10]. Integron class 2 was also performed using 2 primers imAs (ACCTTTTTGTCGCATATCCGTG) and imAcs2 (TACCTGTTCTGCCCGTATCT) [10].

\section{Random Amplified Polymorphic DNA Analysis (RAPD)}

RAPD was performed for all isolates. Isolates were cultured overnight on Nutritive agar and genomic DNA was extracted by phenol - chlorophorm method. Two arbitrarily primers namely; VIL 1 (5' CCGCAGCCAA 3'), VIL5 (5' AACGCGCAAC 3') were used according to the procedure described by Johannes et al. [11]. Clusters analysis was performed by the unweighted pair group method with mathematic averaging UPGMA ( $1 \%$ tolerance, $1 \%$ Dice coefficient) and the cut off was fixed to $90 \%$ of similarity. Dendrograms were performed using Fingerprinting II software (Bio-Rad laboratories, Germany).

\section{Pulsed Field Gel Electrophoresis (PFGE)}

PFGE was performed using a consensus protocol for A. baumannii typing with Apa I [12]. Electrophoresis was done in CHEF Mapper
Apparatus in run conditions $\left(19 \mathrm{H}, 14^{\circ} \mathrm{C}\right.$, initial and final switch times of $5 \mathrm{~s}$ and $35 \mathrm{~s}$, linear ramp and $6 \mathrm{~V} / \mathrm{cm})$. Clusters analysis and dendrograms were performed as mentioned below.

\section{$A d e B$ gene detection and sequencing}

Detection and partial sequence analysis of $a d e B$ was performed with previously published pair primers O3 (5'GTATGAATTGATGCTGC3') and $\mathrm{O} 4$ (5'CACTCGTAGCCAATACC3') that target a $850 \mathrm{pb}$ segment $[13,14]$. The PCR product was purified using the QIAquick Purification kit and partial sequencing of $a d e B$ was performed by using the Dye-Ex 2.0 Terminator. Sequence alignment and comparison were performed with the Sequencing Analysis software.

\section{Statistical analysis}

Data were analyzed using $\mathrm{X}^{2}$ test. A $\mathrm{p}$ value of $<0.05$ was considered to be statistically significant.

\section{Results}

\section{Antibiotyping}

The levels of antibiotics resistance for the two hospitals are summarised in (Table 2). The results show that the levels had achieved the same degree of resistance except for imipenem which was two times higher for the Tunisian isolates. The difference of imipenem level resistance was statistically significant $(\mathrm{p}<0.05)$. (Table 2$)$ illustrates the distribution of antibiotics resistance combinations among strains; French isolates had generated 6 uniformed clusters. Therefore, Tunisian isolates were scattered in 12 clusters by the same classification representing different combinations of antibiotics resistance with 5 clusters containing only one isolate.

\section{Epidemiological data}

The epidemiological data collected from the studied hospitals showed a large difference in the imipenem consumption. For the

\begin{tabular}{|c|c|c|c|c|c|c|c|c|c|c|}
\hline & \multirow{2}{*}{$\begin{array}{l}\text { Resistance } \\
\text { phenotype } \\
\text { designation }^{a}\end{array}$} & \multirow[t]{2}{*}{$\begin{array}{l}\text { No. } \\
\text { Isolate }^{b}\end{array}$} & \multicolumn{8}{|c|}{ Antibiogram (disk zone size, $\mathrm{mm})^{c}$} \\
\hline & & & GM & TM & AN & CAZ & TE & RA & CIP & IPM \\
\hline \multicolumn{3}{|c|}{ Number of resistant strains (\%) } & $21(68)$ & $22(71)$ & $17(55)$ & $31(100)$ & $13(42)$ & $13(42)$ & $4(13)$ & 27 (87) \\
\hline \multirow{6}{*}{ French strains } & A & 14 & 9 & 6 & 11 & 6 & 6 & 20 & 6 & 24 \\
\hline & B & 3 & 6 & 6 & 7 & 6 & 6 & 21 & 6 & 25 \\
\hline & $\mathrm{C}$ & 4 & 16 & 17 & 19 & 19 & 9 & 17 & 6 & 31 \\
\hline & D & 5 & 20 & 11 & 17 & 15 & 8 & 17 & 6 & 27 \\
\hline & $E$ & 1 & 24 & 22 & 22 & 12 & 6 & 23 & 6 & 32 \\
\hline & $\mathrm{F}$ & 4 & 9 & 18 & 18 & 6 & 6 & 18 & 6 & 21 \\
\hline \multicolumn{3}{|c|}{ Number of resistant strains (\%) } & $23(74)$ & $14(45)$ & $14(45)$ & $30(98)$ & $28(90)$ & $19(61)$ & $11(36)$ & $30(98)$ \\
\hline \multirow{12}{*}{ Tunisian strains } & $a_{1}$ & 5 & 8 & 20 & 22 & 6 & 6 & 20 & 6 & 30 \\
\hline & $b_{1}$ & 4 & 8 & 18 & 20 & 6 & 6 & 20 & 18 & 28 \\
\hline & $\mathrm{c}_{1}$ & 1 & 10 & 20 & 22 & 6 & 10 & 17 & 6 & 15 \\
\hline & $d_{1}$ & 1 & 12 & 20 & 14 & 18 & 18 & 17 & 17 & 22 \\
\hline & $\mathrm{e}_{1}$ & 7 & 8 & 8 & 10 & 6 & 6 & 18 & 6 & 27 \\
\hline & $\mathrm{f}_{1}$ & 4 & 6 & 6 & 6 & 6 & 6 & 18 & 6 & 8 \\
\hline & $g_{1}$ & 2 & 20 & 20 & 6 & 6 & 15 & 22 & 6 & 17 \\
\hline & $h_{1}$ & 2 & 16 & 6 & 22 & 13 & 12 & 6 & 6 & 30 \\
\hline & $i_{1}$ & 1 & 6 & 6 & 20 & 12 & 12 & 18 & 6 & 30 \\
\hline & $\mathrm{j}_{1}$ & 1 & 26 & 23 & 25 & 6 & 6 & 6 & 6 & 10 \\
\hline & $\mathrm{k}_{1}$ & 2 & 16 & 18 & 19 & 6 & 14 & 6 & 23 & 12 \\
\hline & $I_{1}$ & 1 & 25 & 25 & 25 & 21 & 20 & 22 & 32 & 35 \\
\hline
\end{tabular}

aAntibiograms with a similarity coefficient of $\geq 0.9$ were considered indistinguishable and were grouped together in a single resistance phenotype designation bumbers of isolates

'Antibiotics designations: GM, gentamicin; TM, tobramycin; AN, amikacin; CAZ, ceftazidim;TE, tetracycline; RA, rifampicin; CIP, ciprofloxacin; IPM, imipenem Diameter of the disk of antibiotic: $6 \mathrm{~mm}$ 
Citation: Ben Othman A, Burucoa C, Battikh H, Zribi M, Masmoudi A, et al. (2011) Comparison of Acinetobacter baumannii multidrugs resistant Isolates obtained from French and Tunisian hospitals. J Bacteriol Parasitol 2:106. doi:10.4172/2155-9597.1000106

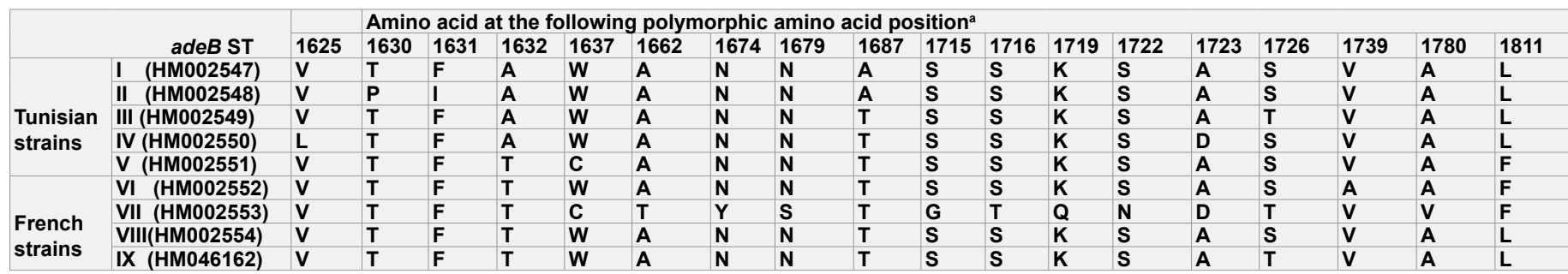

aAligned nucleotide sequences of partial adeB fragments (position 1632 to 2484 ) according to the numbering of the adeB sequence with EMBL accession no. AF370885 Table 2: Polymorphic amino acid position in 9 adeB STs of $A$. baumannii strains isolated from Tunisian and French hospitals.

\begin{tabular}{|c|c|c|c|c|c|c|c|}
\hline No isolates & date of isolement & unit of isolement ${ }^{a}$ & $\begin{array}{l}\text { clusters of RAPD } \\
\text { typing }^{\mathrm{b}}\end{array}$ & $\begin{array}{l}\text { clusters of PFGE } \\
\text { typing }^{c}\end{array}$ & $\begin{array}{l}\text { Antibiogram } \\
\text { patterns in cluster }\end{array}$ & $\begin{array}{l}\text { Integron1 } \\
\text { detection }\end{array}$ & $\begin{array}{l}\text { Accenssion number } \\
\text { of abeB gene }\end{array}$ \\
\hline 32 & 27.02 .05 & surgery- ICU & $\mathrm{B}$ & 1 & a & $(-)$ & ST VI \\
\hline 33 & 11.04 .05 & surgery- ICU & B & 1 & a & $(-)$ & ST VI \\
\hline 34 & 20.05 .05 & surgery- ICU & B & 1 & a & $(-)$ & ST VI \\
\hline 35 & 15.09 .03 & other unit & B & 1 & a & $(-)$ & ST VI \\
\hline 36 & 11.03 .04 & Visceral surgery & B & 1 & a & $(-)$ & ST VI \\
\hline 37 & 04.08 .05 & surgery- ICU & B & 1 & a & $(-)$ & ST VI \\
\hline 38 & 19.07.04 & other unit & B & 1 & a & $(-)$ & ST VI \\
\hline 39 & 20.07.04 & other unit & B & 1 & a & $(-)$ & ST VI \\
\hline 40 & 11.10 .03 & other unit & B & 1 & a & $(-)$ & ST VI \\
\hline 41 & 27.08 .03 & other unit & B & 1 & a & $(-)$ & ST VI \\
\hline 42 & 01.12 .03 & Transfered from another hospital & B & 1 & a & $(-)$ & ST VI \\
\hline 43 & 16.10 .03 & other unit & B & 1 & a & $(-)$ & ST VI \\
\hline 44 & 03.11 .03 & other unit & B & 1 & a & $(-)$ & ST VI \\
\hline 45 & 07.07 .03 & surgery- ICU & B & 1 & a & $(-)$ & ST VI \\
\hline 46 & 25.12 .04 & surgery- ICU & C & 2 & b & $(-)$ & ST IX \\
\hline 47 & 15.08 .04 & surgery- ICU & C & 2 & b & $(-)$ & ST IX \\
\hline 48 & 12.07 .04 & transfer from another hospital & $\mathrm{C}$ & 2 & b & $(-)$ & ST IX \\
\hline 49 & 20.01 .04 & other unit & C & 2 & c & $(-)$ & ST IX \\
\hline 50 & 04.11 .03 & other unit & C & 2 & c & $(-)$ & ST IX \\
\hline 51 & 11.10.03 & other unit & C & 2 & c & $(-)$ & ST IX \\
\hline 52 & 31.08 .03 & surgery- ICU & C & 2 & c & $(-)$ & ST IX \\
\hline 53 & 15.03 .03 & surgery- ICU & D & 3 & d & $820 \mathrm{pb}$ & ST VII \\
\hline 54 & 13.10 .03 & other unit & D & 3 & d & $820 \mathrm{pb}$ & ST VII \\
\hline 55 & 25.08 .03 & other unit & D & 3 & d & $820 \mathrm{pb}$ & ST VII \\
\hline 56 & 03.09 .03 & other unit & $D$ & 3 & d & $820 \mathrm{pb}$ & ST VI \\
\hline 57 & 13.10 .03 & other unit & D & 3 & d & $820 \mathrm{pb}$ & ST VII \\
\hline 58 & 12.08 .05 & surgery- ICU & A & 4 & e & $(-)$ & ST VIII \\
\hline 59 & 03.02 .04 & surgery- ICU & A & 4 & f & $(-)$ & ST VIII \\
\hline 60 & 31.01 .04 & surgery- ICU & A & 4 & $f$ & $(-)$ & ST VIII \\
\hline 61 & 16.02 .04 & surgery- ICU & A & 4 & $f$ & $(-)$ & ST VIII \\
\hline 62 & 22.12.05 & surgery- ICU & A & 4 & $f$ & $(-)$ & ST VIII \\
\hline
\end{tabular}

aCU: intensive care unit

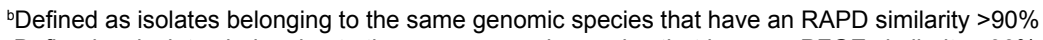

'Defined as isolates belonging to the same genomic species that have an PFGE similarity $>90 \%$

${ }^{\mathrm{d}}$ Antibiogram patterns as defined in the table 2

Table 3: Summary of the molecular and antibiogram clusters Nosocomial Acinectobacter baumannii isolates in the French hospital.

French hospital the imipenem DDD, despite the higher frequency of the number of hospitalisation days in Poitiers' hospital with regard to La Rabta one, we observed a stable and moderate DDD imipenem consumption that passed of 2.22 in 2005 to 2.26 in 2007 . In contrast, the Tunisian hospital achieved a higher imipemen consumption fluctuation where DDD passed of 10.1 in 2005 to 12.04 in 2007. The difference between DDD levels under the two years study were statistically significant $(\mathrm{p}<0.05)$.

\section{PCR detection of Integrons class 1 and 2}

Integron 1 was detected in 5 French isolates (13\%) generating an 820bp fragment. 9 (29\%) Tunisian isolates showed the integron class 1 (4 strains (820bp), 4 strains $(2.2 \mathrm{~kb})$ and 1 strain $(820 \mathrm{bp}+2.2 \mathrm{~kb}))$. Class 2 integron was not detected in both hospitals.

\section{Random Amplified Polymorphic DNA Analysis (RAPD)}

All strains were typed by RAPD. Profiles generated 4 and 6 groups for French and Tunisian isolates respectively (Figure 1). The 2 strains collections presented different profiles.

\section{Pulsed Field Gel Electrophoresis (PFGE)}

PFGE typing method defined respectively 4 and 6 different groups for European and Tunisian isolates which are illustrated in (Figure 2). The 2 strains collections presented different profiles.

\section{$A d e B$ gene detection and sequencing}

All isolates presented the $a d e B$ gene. A selection of sequences representing the 9 adeB sequences types reported in this study has been submitted to EMBL Gene Bank. They all showed new mutations 
Citation: Ben Othman A, Burucoa C, Battikh H, Zribi M, Masmoudi A, et al. (2011) Comparison of Acinetobacter baumannii multidrugs resistant Isolates obtained from French and Tunisian hospitals. J Bacteriol Parasitol 2:106. doi:10.4172/2155-9597.1000106

Page 4 of 7

\begin{tabular}{|c|c|c|c|c|c|c|c|}
\hline No isolates & $\begin{array}{l}\text { Date of } \\
\text { isolement }\end{array}$ & Unit of isolement ${ }^{a}$ & $\begin{array}{l}\text { Clusters of RAPD } \\
\text { typing }^{\text {b }}\end{array}$ & $\begin{array}{l}\text { Clusters of PFGE } \\
\text { typing }\end{array}$ & $\begin{array}{l}\text { Antibiogram patterns in } \\
\text { cluster }^{d}\end{array}$ & Integron1 detection & $\begin{array}{l}\text { Accenssion number of abeB } \\
\text { gene }\end{array}$ \\
\hline 1 & 06.01 .04 & ICU & F1 & 1 & $a_{1}$ & $820 \mathrm{bp}$ & ST IV \\
\hline 2 & 13.10.04 & Surgery & F1 & 1 & $a_{1}$ & $820 p b+2,2 K b$ & ST IV \\
\hline 3 & 24.07 .05 & ICU & F1 & 1 & $a_{1}$ & $(-)$ & ST IV \\
\hline 4 & 27.10 .04 & ICU & C1 & 2 & $a_{1}$ & $(-)$ & ST III \\
\hline 5 & 20.09 .04 & ICU & C1 & 2 & $a_{1}$ & $2,2 \mathrm{~Kb}$ & ST III \\
\hline 11 & 15.06 .04 & ICU & C1 & 2 & $\mathrm{~d}_{1}$ & $(-)$ & ST III \\
\hline 13 & 06.06 .05 & CVU & C1 & 2 & $e_{1}$ & $820 \mathrm{pb}$ & ST III \\
\hline 15 & 02.04 .05 & other unit & C1 & 2 & $e_{1}$ & $2.2 \mathrm{~Kb}$ & ST III \\
\hline 29 & 13.12 .05 & other unit & C1 & 2 & $k_{1}$ & $(-)$ & ST III \\
\hline 6 & 19.10 .05 & ICU & G1 & 3 & $b_{1}$ & $(-)$ & ST V \\
\hline 9 & 23.10 .05 & ICU & G1 & 3 & $b_{1}$ & $2,2 \mathrm{~Kb}$ & ST V \\
\hline 7 & 25.10 .05 & other unit & G1 & 3 & $b_{1}$ & $2,2 \mathrm{~Kb}$ & ST V \\
\hline 10 & 30.01 .05 & ICU & G1 & 3 & $\mathrm{c}_{1}$ & $(-)$ & ST V \\
\hline 23 & 22.01 .05 & ICU & G1 & 3 & $g_{1}$ & $(-)$ & ST V \\
\hline 27 & 12.04 .04 & other unit & G1 & 3 & $i_{1}$ & $(-)$ & ST V \\
\hline 28 & 10.10.05 & ICU & G1 & 3 & $\mathrm{j}_{1}$ & $(-)$ & ST V \\
\hline 12 & 10.01 .05 & CVU & G1 & 3 & $\mathrm{e}_{1}$ & $(-)$ & ST V \\
\hline 16 & 13.09.04 & ICU & G1 & 3 & $e_{1}$ & $820 \mathrm{pb}$ & ST V \\
\hline 14 & 23.03 .05 & ICU & B1 & 4 & $e_{1}$ & $820 \mathrm{pb}$ & AF 390885 \\
\hline 25 & 22.01 .04 & ICU & B1 & 4 & $\mathrm{~h}_{1}$ & $(-)$ & AF 390885 \\
\hline 30 & 27.08 .04 & Surgery & B1 & 4 & $\mathrm{k}_{1}$ & $(-)$ & AF 390885 \\
\hline 17 & 17.08 .05 & ICU & A1 & & $\mathrm{e}_{1}$ & $(-)$ & ST II \\
\hline 18 & 02.06 .05 & CVU & A1 & 5 & $\mathrm{e}_{1}$ & $(-)$ & ST II \\
\hline 19 & 08.02 .05 & ICU & A1 & 5 & $f_{1}$ & $(-)$ & ST II \\
\hline 21 & 24.04 .05 & ICU & A1 & 5 & $\mathrm{f}_{1}$ & $(-)$ & ST II \\
\hline 22 & 24.09 .05 & others unit & A1 & 5 & $\mathrm{f}_{1}$ & $(-)$ & ST II \\
\hline 20 & 14.05 .05 & other unit & E1 & 6 & $\mathrm{f}_{1}$ & $(-)$ & ST I \\
\hline 24 & 31.05 .05 & Other unit & E1 & 6 & $g_{1}$ & $(-)$ & ST I \\
\hline 26 & 07.10 .05 & other unit & E1 & 6 & $\mathrm{~h}_{1}$ & $(-)$ & ST I \\
\hline 8 & 06.09 .05 & CVU & E1 & 6 & $b_{1}$ & $(-)$ & ST I \\
\hline
\end{tabular}

aCU: intensive care unit ; CVU: cardiovascular unit

bDefined as isolates belonging to the same genomic species that have an RAPD similarity $>90 \%$

'Defined as isolates belonging to the same genomic species that have an PFGEsimilarity $>90 \%$

${ }^{\mathrm{d} A n t i b i o g r a m}$ patterns as defined in the table 2

Table 4: Summary of the molecular and antibiogram clusters of Acinectobacter baumannii isolates from the Tunisian hospital.

which are illustrated in (Table 2) under specific accession numbers (HM002547 to HM002551) in Tunisian strains and (HM046162, HM002552 to HM002554) in French strains.

\section{Combination of typing results}

The combined typing results show a good correlation between genomic methods typing (RAPD, PFGE). Based on partial sequencing analysis, the present study has demonstrated that the delineation of adeB STs among genotypically related strains of Tunisia and France matched extremely well the genotypic clustering of these strains with RAPD and PFGE analysis. A positive correlation was observed between antibiotyping and genotyping for French isolates. In contrast, DNA fingerprinting of Tunisian isolates revealed 7 clusters, each one contained isolates with more than one antibiogram indicating that Tunisian strains acquire more rapidly resistance to antibiotics. (Table $3,4)$.

\section{Discussion}

Acinetobacter, particularly A. baumannii, is implicated in a wide spectrum of nosocomial infections, including primary ventilatorassociated pneumonia in patients confined in intensive care unit, secondary meningitis and urinary tract infections.

In our comparative approach, we specified the antibiotic resistance mechanisms and the epidemiology of A. baumannii isolated in two acute- care hospitals; one in Tunis (North Africa), and the second in Poitiers (France).

The two hospitals have achieved a great level of resistance to the wide range of antibiotics classes. It seems that extensive and increasing use of broad spectrum antibiotics in the hospital had served to eliminate sensitive bacteria and to create a vacant ecological niche to very resistant clones. This multiresistance was observed in several hospitals in the
Europe such as the spread of the Oxa-23 clones in England $[15,16]$, the spread of a VEB-1 ESBL-producing A. baumannii clone in France [17], the dissemination of a multidrug resistant $A$. baumannii clone in Portugal [18] and the emergence and rapid spread of multiresistant $A$. baumannii in a Spain hospital [19]. This finding was also reported in Tunisian publications $[20,21]$. However another Tunisian report also demonstrated that with anti biotherapy restrictions we could reach a significant reduction of resistance to a large range of antibiotics and permit the decrease of the number of carbapenem resistant isolates [22]. The particularities of our study were in relation with the comparison between the 2 hospitals. We observed a difference in the level of impenem resistance: this resistance was higher in the Tunisian hospital (36\%). This finding could be easily explained by the frequent use of this antibiotic in the Rabta hospital because of the high level of Enterobacteriacea and Stenotrophomonas maltophilia $\beta$-lactamases. This finding was confirmed by the imipemem consumption in this present study which showed that the defined daily dose (DDD) relative to this antibiotic in the French hospital is always similar to the dose fixed by the WHO (2.22 to 2.26) and which is higher in our hospital (10.1 to 12.4)

The genomic investigation by RAPD and PFGE methods was useful to identify the epidemic strains of A.baumannii. They showed multiple epidemic strains that persisted two years in some cases in the two hospitals study. The analysis of the molecular epidemiology and multidrug resistance of $A$. baumanni strains in the various parts of the world indicates a considerable degree of geographic diversity in the spread of various strains $[23,24,25,26]$. It's also demonstrated by multiple studies in Tunisia $[20,21,27]$ and in France $[28,29,30]$ that the multiresistance is common among A.baumannii giving nosocomial epidemics which were difficult to treat.

The gene $a d e B$ codes for the transmembrane protein of the AdeABC 
Citation: Ben Othman A, Burucoa C, Battikh H, Zribi M, Masmoudi A, et al. (2011) Comparison of Acinetobacter baumannii multidrugs resistant Isolates obtained from French and Tunisian hospitals. J Bacteriol Parasitol 2:106. doi:10.4172/2155-9597.1000106

Page 5 of 7

(a)

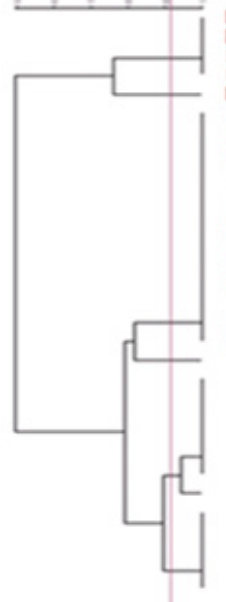

novens novis

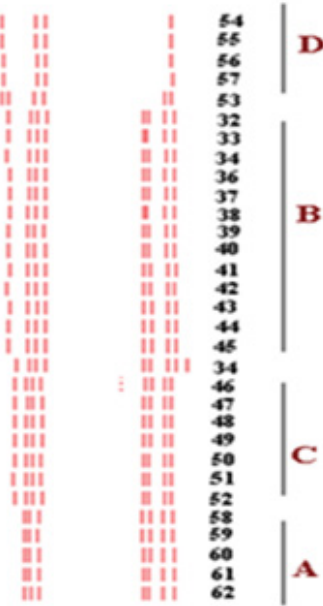

(b)

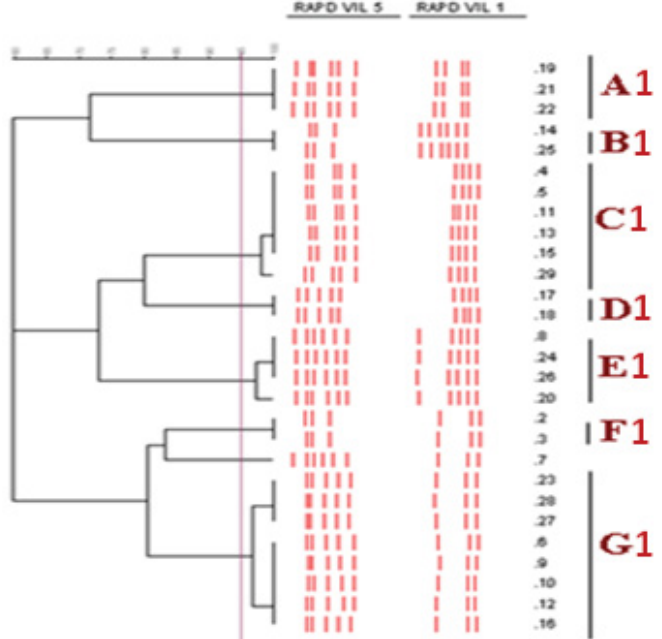

Figure 1: Genetic fingerprinting and clusters of French (a) and Tunisian (b) Acinetobacter baumannii isolates using Random amplified Polymorphic DNA.
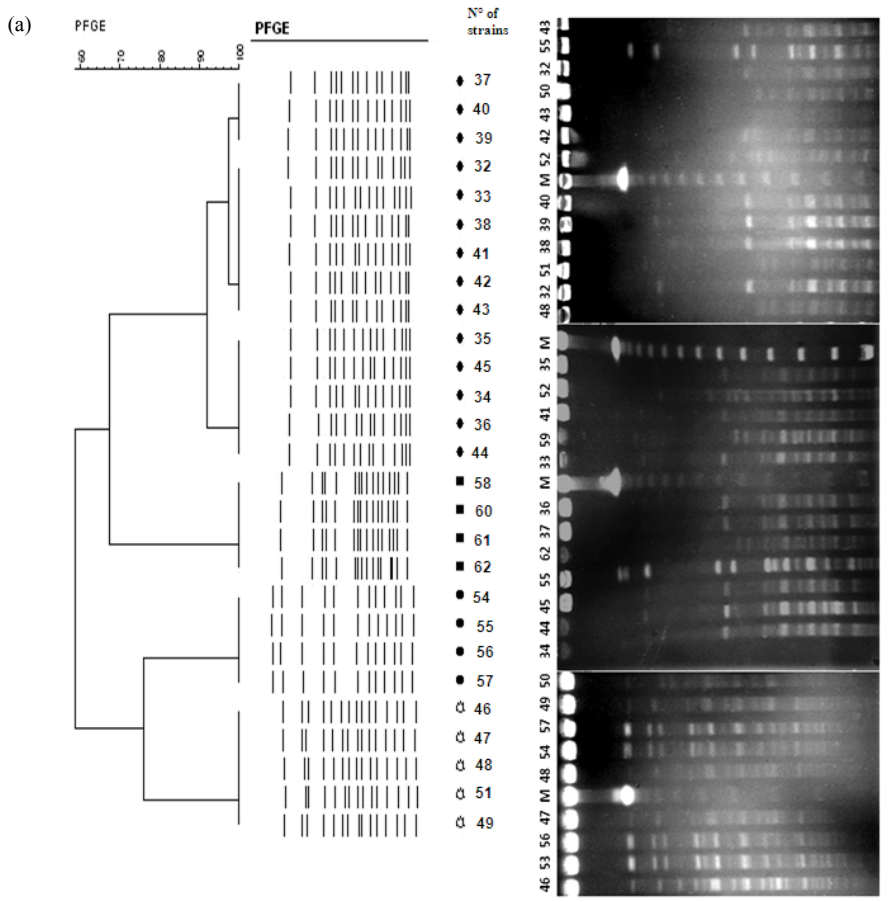

(b)
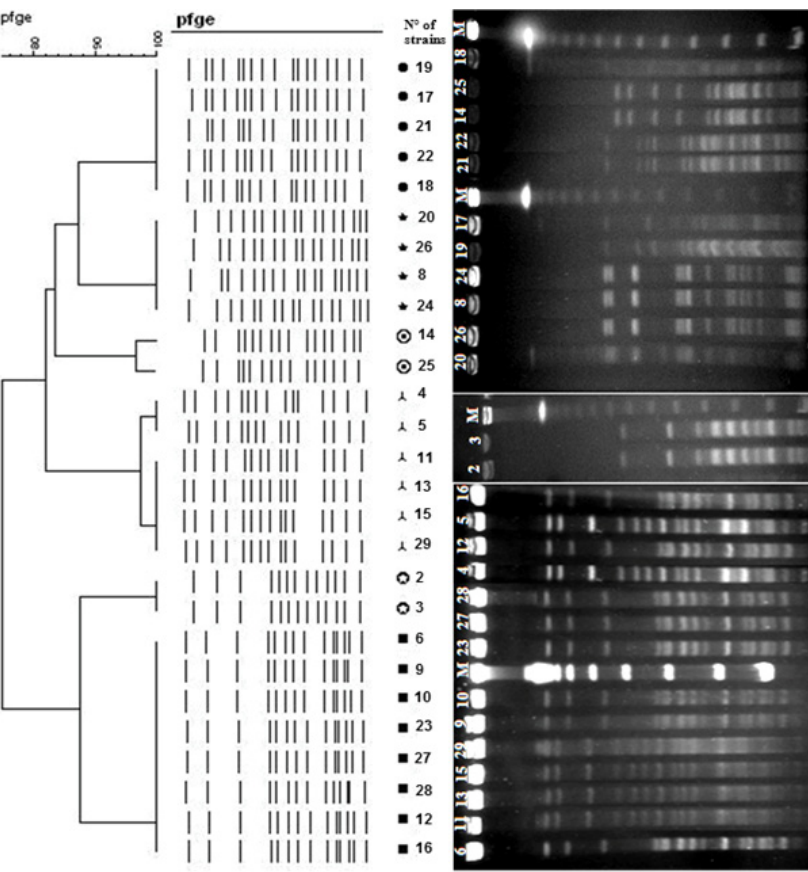

Figure 2: Genetic fingerprinting and clusters of French (a) and Tunisian (b) Acinetobacter baumannii isolates using Pulsed- field gel electrophoresis technique.

multidrug efflux pump has mainly been detected in $A$. baumannii outbreaks strains $[30,31,32]$. All MDR isolates in the present study were found to carry the adeB gene. As described by Magnet et al., these genes specifically confer resistance to aminoglycosides and tetracyclines and disruption of this gene leads to the loss of multidrug resistance [14].

In addition, partial sequence analysis of $a d e B$ gene encoding the aspecific drug efflux gene showed that it's a potential tool to identify intraspecific groups among multidrug resistant A. baumannii strains. In fact, the delineation of adeB STs among genotypically related strains of Tunisia and France corroborated extremely well with the genotypic clustering of these strains with RAPD and PFGE analysis. In addition, sequencing of $a d e B$ gene had placed the strains of the two collections in distinct groups and with new mutations under specific accession numbers designed by EMBL gene bank. This tool was previously used in a number of related studies $[13,30]$.

In this study, we observed epidemic A. baumannii strains with great antibiotic resistance profiles for both hospitals, but the French clones disappeared more quickly. This finding could be explained by greater control disinfections procedures and strict adherence to infection control policies operated in the French hospital (especially hand and environmental hygiene and use of closed suctioning techniques), and discharge of colonized patients from the hospital as soon as possible. Infact, a systematic procedure of nosocomial infections due to multidrug resistant strains declaration was done in all French hospitals 
Citation: Ben Othman A, Burucoa C, Battikh H, Zribi M, Masmoudi A, et al. (2011) Comparison of Acinetobacter baumannii multidrugs resistant Isolates obtained from French and Tunisian hospitals. J Bacteriol Parasitol 2:106. doi:10.4172/2155-9597.1000106

imposed by the CCLIN (centre de coordination de lutte contre les infections nosocomiales).

In the Tunisian hospital, nosocomial infections are not systematically screened and controlled within a national program of health which is still in course of implementation. Deficiencies in the implementation of infection control guidelines in the Tunisian hospital cannot avoid the rapid dissemination of epidemic strains and the evolution of resistance mechanisms as described in previous studies $[20,21,27]$.

Another important factor that can increase the incidence and persistence of nosoccomial infections due to A.baumannii in Tunisia could be the tropical climate (warm and humid). This finding was supported by Siau et al on Hong Kong [33] and another report $[34,35,36]$.

A seasonal increase of Acinetobacter infections during summer may be related to the reduced number of the staff assistant due to the holiday's periods.

This study has demonstrated that there is no statistically significant epidemiological difference between Tunisian and French hospitals. The A. baumannii epidemics that occurred in both hospitals had a significant level of multidrug resistance.

\section{References}

1. Elouennass M, Bajoua T, Lemnouerc AH, Foissaud V, Hervéb V, et al. (2003) Acinetobacter baumannii : susceptibility of strains identified in the military instruction Mohamed V, Rabat, Morocco. Medecine et maladies infectieuses 33: $361-364$

2. Van Dessel H, Dijkshoorn L, Van der Reijden T, Bakker N, Paauw A, et al. (2004) Identification of a new geographically widespread multiresistant Acinetobacter baumannii clone from European hospitals. Research in Microbiology 155: 105112

3. Wang $H$, Guo P, Sun H, Wang H, Yang Q, et al. (2007) Molecular epidemiology of clinical isolates of carbapenem-resistant Acinetobacter spp. from Chinese hospitals. Antimicrob Agents Chemother. 51: 4022-4028.

4. Wu CJ, Lee HC, Lee NY, Shih HI, Ko NY, et al. (2006) Predominance of Gram-negative bacilli and increasing antimicrobial resistance in nosocomial bloodstream infections at a university hospital in southern Taiwan, 1996-2003. J Micro Immunol Infect 39: 135- 140.

5. Herruzo R, de la Cruz J, Fernández-Aceñero MJ, Garcia-Caballero J (2004) Two consecutive outbreaks of Acinetobacter baumanii 1-a in a burn Intensive Care Unit for adults. Burns. 30: 419-23.

6. Stephens C, Francis SJ, Abell V, DiPersio JR, Wells P (2007) Emergence of resistant Acinetobacter baumannii in critically ill patients within an acute care teaching hospital and a long-term acute care hospital. Am J Infect Control. 35: $212-5$

7. Tan L, Sun X, Zhu X, Zhang Z, Li J, et al. (2004) Epidemiology of nosocomial pneumonia in infants after cardiac surgery. Chest 25: 410-7

8. Webster C, Towner KJ, Saunder G, Crewe-Brown H, Humphreys H (1999) Molecular and Antibiogram relationship of Acinetobacter isolates from two contrasting hospitals in the United Kingdom and South Africa. Eur JClin Microbiol Dis. 18: 595- 598

9. Horrevorts A, Bergman V, Kolle'e V, Breuker I, Tjernberg I, et al. (1995) Clinical and Epidemiological Investigations of Acinetobacter Genomospecies 3 in a Neonatal Intensive Care Unit. J. Clin. Microbial. 33: 1567-1572.

10. Ploy MC, Denis F, Courvalin P, Lambert T (2000) Molecular Characterization of Integrons in Acinetobacter baumannii: Description of a Hybrid Class 2 Integron. Ant. Agents. Chemother. 44: 2684-2688.

11. Johannes GMK, Jeroen stoff, Biesmans DJ, Savelkoul PH, VandenbrouckeGrauls CMJE, et al. (1998) Comparison of Amplified Ribosomal DNA Restriction Analysis, Random Amplified Polymorphic DNA Analysis, and Amplified Fragment Length Polymorphism Fingerprinting for Identification of Acinetobacter Genomic Species and Typing of Acinetobacter baumannii. J Clin Microbiol 36: 2522-2529.
12. Seifert $H$, Dolzani $L$, Bressan R, van der Reijden T, van Strijen B, et al. ( 2005) Standardization and interlaboratory reproducibility assessement of PulsedField Gel Electrophoresis- Generated Fingerprints of Acinetobacter baumannii. J Clin Microbial 43: 4328-4335.

13. Huys G, Cnockaert M, Nemec A, Swings J (2005) Sequence-Based Typing of adeB as a Potential Tool To Identify Intraspecific Groups among Clinical Strains of Multidrug-Resistant Acinetobacter baumannii. J. Clin. Microbiol. 43: 53275331.

14. Magnet S, Courvalin P, Lambert T (2001) Resistance-Nodulation-Cell DivisionType Efflux Pump Involved in Aminoglycoside Resistance in Acinetobacter baumannii Strain BM4454. Antimicrob Agents Chemother 45: 3375-3380.

15. Coelho JM, Turton JF, Kaufmann ME, Glover J, Woodford N, et al. (2006) Occurrence of carbapenem-resistant Acinetobacter baumannii clones at multiple hospitals in London and Southeast England. J. Clin Microbiol. 44:36233627.

16. Turton JF, Kaufmann ME, Warner M, Coelho J, Dijkshoorn L, et al. (2004) A prevalent, multiresistant clone of Acinetobacter baumannii in Southeas England. J. Hosp. Infect. 58:170-179.

17. Naas T, Coignard B, Carbonne A, Blanckaert K, Bajolet O, et al. (2006) VEB1 extended-spectrum beta-lactamase-producing Acinetobacter baumannii, France. Emerg. Infect. Dis. 12: 1214-1222.

18. Da Silva G, Dijkshoorn L, van der Reijden T, B van Strijen, Duarte A (2007) Identification of widespread, closely related Acinetobacte baumannii isolates in Portugal as a subgroup of European clone II. Clin. Microbiol. Infect. 13: 190195

19. Xavier Corbella, Abelardo Montero, Miquel Pujol, Angeles Domínguez M, Josefina Ayats, et al. (2000) Emergence and Rapid Spread of Carbapenem Resistance during a Large and Sustained Hospital Outbreak of Multiresistant Acinetobacter baumannii. 38(11): 4086-4095.

20. Saidani M, Boutiba I, Ghozzi R, Kammoun A, Ben Rejeb S (2006) Bacteriological profile of bacteremia due to multi-drug resistant bacteria at Charles- Nicolle hospital of Tunis. Med Mal Infect. 36: 163-166.

21. Mansour W, Bouallegue O, Dahmen S, Boujaafer N (2005) Characterization of the resistance to beta lactams in Acinetobacter baumannii strains isolated in the university hospital Sahloul in Tunisia. Pathologie Biologie. 56 (116-120).

22. Brahmi N, Blela Y, Kouraichia N, Ben Hamoudaa R, Thabeta H, et al. (2006) Impact of antibiotic use and prescribing policy in a Tunisian intensive care unit Medecine et maladies infectieuses. $36: 460-465$.

23. Chao Qi, Malczynski M, Parker M, Scheetz MH (2008) Characterization of Genetic Diversity of Carbapenem-Resistant Acinetobacter baumannii Clinical Strains Collected from 2004 to 2007. J Clin Microbiol. 46: 1106-1109.

24. Landman D, Quale JM, Mayorga D, Adedeji M, Vangala K, et al. ( 2002) Citywide Clonal Outbreak of Multiresistant Acinetobacter baumannii and Pseudomonas aeruginosa in Brooklyn, NY. Arch Intern Med 162: 160-163.

25. Zarrilli1 R, Giannouli M, Tomasone F, Triassi1 M, Tsakris A (2009) Carbapenem resistance in Acinetobacter baumannii: the molecular epidemic features of an emerging problem in health care facilities. J Infect Dev Ctries 3: 335-341.

26. Marchaim D, Navon-Venezia S, Leavitt A, Chmelnitsky I, Schwaber MJ, et al. (2007) Molecular and Epidemiologic Studyof Polyclonal Outbreaks of Multidrug-Resistant Acinetobacter baumannii Infection in an Israeli Hospital. Infect Control Hosp Epidemiol 28: 1350- 1354.

27. Poirel L, Mansour W, Bouallegue O, Nordmann P (2008) Carbapenem Resistant Acinetobacter baumannii Isolates from Tunisia Producing the OXA58-Like Carbapenem-Hydrolyzing Oxacillinase OXA-97. Antimicrob. Agents and Chemother 52: 1613-1617.

28. Pimentel JD, Low J, Styles K, Harris OC, Hughes A, et al. (2005) Control of an outbreak of multi-drug-resistant Acinetobacter baumannii in an intensive care unit and a surgical ward. J. Hospital Infection. 59:249-253.

29. Fournier PE, Vallenet D, Barbe V, Audic S, Gata H, et al. (2006) Comparative Genomics of Multidrug Resistance in Acinetobacter baumannii. PLoS Genetics 2: $7-10$

30. Higgins PG, Wisplinghoff $H$, Stefanik M, Seifert H (2004) Selection of topoisomerase mutations and over expression of adeB mRNA transcripts during an outbreak of Acinetobacter baumannii. J. Antimicrob. Chemother 54 821-823. 
Citation: Ben Othman A, Burucoa C, Battikh H, Zribi M, Masmoudi A, et al. (2011) Comparison of Acinetobacter baumannii multidrugs resistant Isolates obtained from French and Tunisian hospitals. J Bacteriol Parasitol 2:106. doi:10.4172/2155-9597.1000106

31. Huys G, Cnockaert M, Nemec A, Dijkshoorn L, Brisse S, et al. (2005) RepetitiveDNA-element PCR fingerprinting and antibiotic resistance of pan-European multi-resistant Acinetobacter baumannii clone III strains. Journal of Medical Microbiology, 54: 851-856.

32. Huys G, Cnockaert M, Vaneechoutte M, Woodford N, Nemec A, et al. (2005) Distribution of tetracycline resistance genes in genotypically related and unrelated multi-resistant Acinetobacter baumannii strains from different European hospitals. Res Microbiol 156 348-355

33. Siau H, Yuen KY, Wong SSY, Ho PL, Luk WK (1996) The epidemiology of acinetobacter infections in Hong Kong. J. Med. Microbiol. 44: 340-347.
34. Podnos YD, Cinat ME, Wilson SE, Cooke J, Gornick W, et al. (2001) Eradication of multidrug-resistant Acinetobacter from an intensive care unit. Surg Infect 2 297-301.

35. Denton M, Wilcox MH, Parnell P, Greenc D, Keera V, et al. (2005) Role of environmental cleaning in controlling an outbreak of Acinetobacter baumannii on a neurosurgical intensive care unit. Intensive and Critical Care Nursing 21:94-98.

36. Chim H, Hock B, Song C (2007) Five-year review of infections in a burn intensive care unit: High incidence of Acinetobacter baumannii in a tropical climate. Burns, 33: 1008-101. 